\title{
Commercialization of Space Activities: Correlation of Private and Public Interest in the Pursuit of Outer Space Exploration
}

\author{
Oleksandr Svetlichnyj
}

Doctor of Law, Associate Professor, National University of Life and Environmental Sciences of Ukraine (Kyiv, Ukraine)

E-mail: a.svetlichnyj@ukr.net https://orcid.org/0000-0003-0485-3804

\section{Diana Levchenko}

Master Degree in Law, researcher, Scientific Institute of Public Law (Kyiv, Ukraine) E-mail: diana.levchenko5@gmail.com https//orcid.org/0000-0001-8343-2260

The article reveals the issues of space exploration by private entities who have intensified their efforts in space activities. The US and Luxembourg legal regulations, which both govern the private sector involvement in State space activities and allow citizens to freely engage in the development of planets and asteroids, to own and dispose of resources, including water and minerals, are under analysis. Therefore, due to the occurrence of legal collisions, the International Law Association and the Space Law Committee, established on its basis, should influence regulating space issues. These institutions are known for their open policies and extensive external relations. Their key mission is to study, clarify and develop international public and private law and prepare comparative law research. The author concludes that being an important human resource, space objects and natural resources should belong to all humanity, not to individual States or private enterprises. The adoption of the US and Luxembourg legislation on legalizing, extracting, using and appropriating space resources by private enterprises seems to be in full compliance with international obligations, however, in fact they violate the principles governing the activities of States in the exploration and use of outer space, including the moon and other celestial bodies, which are not subject to national appropriation, neither by proclaiming sovereignty, nor by uses or occupation, nor by any other means.

Keywords: ownership, space objects, natural resources, international space law, regulations, organization

Received: August 28, 2019; accepted: October 07, 2019

Advanced Space Law, Volume 4, 2019: 80-91.

https://doi.org/10.29202/asl/2019/4/8

(C) Svetlichnyj, Oleksandr, 2019

(C) Levchenko, Diana, 2019 


\section{Problem statement}

Speaking about the development of rocket and space engineering, astronautics and other space activities in Ukraine, the world usually connects this with the name of a famous rocket pioneer Mykola Kybalchych, who was born in Korop, Chernihiv region. Back in the nineteenth century, he developed a unique aircraft project that could carry out space-flight missions. In 1916, Yurii Kondratiuk made calculations for the manned flight to the Moon. Americans used these calculations when they sent their astronauts to the satellite. Serhii Koroliov, who was born in the city of Zhytomyr, was an outstanding pioneer of practical cosmonautics. In 1957, the first artificial Earth satellite was launched under his guidance. Valentyn Hlushko was a general designer of rockets. He constructed the world's first electrothermal rocket engine and the first liquid-fuel rocket engines. A valuable contribution to the development of astronautics was made by Ukrainian enterprises, i.e. the Dnipropetrovsk Southern Machine-Building Plant and the Design Bureau "Southern". In 1957, a military missile carrier "Kosmos" was created and successfully used for space flights. The Meteor spacecraft and military communications satellite "Strela" were also in the extensive use.

Nowadays, Ukraine takes an active part in the exploration of the infinite expanses of the Universe, developing and launching spacecraft. Due to the rapid technological progress, astronomers make new discoveries in the universe. One of the largest craters of the planet Mercury is named after Taras Shevchenko. What is more, among the craters on Venus there is one named after the astronomer and geophysicist Zinaida Aksenteva. Another crater on Mars is named after the Kharkiv planetologist Mykola Barabashov, and two others - in honor of the cities of Yevpatoriya and Fastiv. Finally, one of the satellites of Jupiter perpetuated the name of the ancient Kyiv chronicler Nestor. On the Moon, twelve craters bear the names of Ukrainian scientists, including Yurii Kondratiuk, Serhii Koroliov and Volodymyr Vernadsky. A stony asteroid from the inner regions of the asteroid belt-1709 Ukraina was named in honor of Ukraine. There are also asteroids Odesa, Poltava, Dykanka, Kherson, Kakhovka, Sumiana (in honor of the city of Sumy), and dozens of other small planets in the interstellar space bear Crimean names. Among these are Kobzar (in honor of Taras Shevchenko), Kamenyar (in honor of Ivan Franko), Lesya (in honor of Lesya Ukrainka), as well as Skovoroda, Hohol, Narbut, Korolenko, Paradjanov, Dovzhenko, Bykov, Babel and many others. Moreover, there are asteroids Knushevia (in honor of the Taras Shevchenko National University of Kyiv) and Kyivtech (in honor of the Kyiv Polytechnic Institute) [Halaktyka, 2018].

However, the space objects registered in the international catalog are not Ukraine's property. What is in general consistent with international law, in particular, "Treaty on principles governing the activities of states in the exploration and use of outer space, including the moon and other celestial bodies" (Outer Space Treaty) [Treaty, 1967]. However, in practice, as a result of unclear provisions of international law and existing legal gaps in the "Outer Space Treaty", certain individuals, in fact, appropriate space objects that are the property of the whole community [Svitlychnyy, 2019].

The aim of the article is to reveal the peculiarities of the ownership of space objects, as well as to analyze regulations and scientific opinions on the use of space natural resources, to determine and outline the immediate prospects for further development of international space law and structure of the United Nations. 


\section{Main research areas}

Dennis M. Hope is an American man who believes that he is now planet overlord of the moon, but the most interesting thing is that many people truly consider him as such. No one denies his business subdividing extraterrestrial land and selling it off in chunks. Contrary to popular belief, ownership by individuals of extraterrestrial properties is not forbidden. The 1967 UN Outer Space Treaty stipulates that no government can own extraterrestrial property, but it neglected to mention individuals or corporations.

In 1980, Dennis M. Hope sent the United Nations a declaration of ownership detailing his intent to subdivide and sell all planets in our Solar System and their moons. The US government had several years to contest such a claim, which they never did. This allowed Mr. Hope to take the next step and copyright his work with the US Copyright registry office. So, with his claim and Copyright Registration Certificate from the US Government in hand, Mr. Hope became what is probably the largest landowner on the planet today. Since then the Lunar Embassy has sold more than 611 million acres of land on the moon as well as properties on Mars, Venus, Mercury and IO.

Today, The Lunar Embassy has official representations in 35 countries around the world: Canada, UK, Ireland, France, Japan, Australia, Finland and others. Moreover, authorized sales offices of extraterrestrial real estate were established in Germany, the Baltic States, Ukraine, Israel. The Lunar Embassy is the only company in the world to possess a legal basis and copyright for the sale of land on the Moon, and other extraterrestrial property within the confines of our Solar System. About 5 million people from 193 countries have already purchased acres of land on the Moon. Among the owners of land plots are famous politicians, NASA astronauts, world sport stars, actors and music stars [Lunar, 2019].

The United States Government updated U.S. commercial space legislation in 2015 with the passage of the Commercial Space Launch Competitiveness Act. The update to US law explicitly allows US citizens to engage in the commercial exploration and exploitation of space resources including water and minerals. The right does not extend to biological life, so anything that is alive may not be exploited commercially [US Commercial, 2015].

Tanja Masson-Zwaan - president of the International Institute of Space Law considers the new U.S. space resources law to be helpful to commercial interests, since it explicitly codifies rights for the private sector that were only implicit in the 1967 Outer Space Treaty. It adds a level of certainty to the prospects of off-Earth resource harvesting in the eyes of investors, and provides a solid foundation for building additional supportive regulatory frameworks in the United States and elsewhere for commercial lunar and other space resource focused activities of the private sector [Masson-Zwaan \& Richards, 2015].

In this regard, International Institute of Space Law stated its official position, adopted by consensus by the Board of Directors on 20 December 2015. It was mentioned that in view of the absence of a clear prohibition of the taking of resources in the Outer Space Treaty one can conclude that the use of space resources is permitted. Viewed from this perspective, the new United States Act is a possible interpretation of the Outer Space Treaty. Whether and to what extent this interpretation is shared by other States remains to be seen [Position, 2015].

What is more, other normative acts also contributed to the update of U.S. commercial space legislation. In particular, Agreement Governing the Activities of States on the Moon and Other Celestial Bodies adopted by the General Assembly in 1979 in resolution 34/68. The Agreement provides that the Moon and its natural resources are the common heritage of mankind and that an international regime should be established to govern the exploitation of such resources 
when such exploitation is about to become feasible [Agreement, 1979].

The morality crisis leads to the fact that US citizens will fulfil their own material interests at the expense of space objects that are the property of all mankind. To this should be added the fact that in the United States, the question of legal regulation of social relations raises many questions. As Justice Oliver Wendell Holmes wrote in the Harvard Law Review, the law is a "standard which we hold the parties to know beforehand, but not a matter dependent upon the whim of the particular jury". Unfortunately, according to Philip Howard, there is no such standard in US justice [Howard, 2002].

By US law, property is divided into:

1. Real property (realty, real estate): the land and everything connected with it;

2. Personal property (personalty, shattel): all other types of property, that is, actually movable property.

The right to real estate consists, legally speaking, of the title to land and everything located on and above the ground surface, including airspace (with aviation restrictions) as well as underground, including groundwater and fossil fuels, unless otherwise provided by statutory or common law [Tiahai, 2011].

The property rights system 's diversity is achieved through the inclusion of extortion. The bottom line is to ensure the possibility of a person becoming the absolute owner of real estate. The legal category, to which reference is made in this article, endows the actors with a real right [Tiahai, 2011].

In the People's Republic of China, the regulation of property rights is carried out in accordance with the Real Right Law of the People's Republic of China, which has been adopted at the 5th session of the Tenth National People's Congress on March 16, 2007 and went into effect on October 1, 2007. Acquisition and realization of real rights must comply with the legislation, norms of public morality, and not harm the public interests and legitimate interests of other persons (Article 7). According to Art. 24 of the People's Republic of China regime of movable property may be distributed by watercraft, aircraft and motor vehicles [Zakon, 2007].

In accordance with the Article 130 of the Civil Code of the Russian Federation, which is called "Immovable and movable things", the following are categorized as immovable things (immovable property, immovables): land parcels, natural resource parcels, separate water objects and everything that is firmly connected with land, i.e., objects, objects whose movement is impossible without disproportionate harm to their use, including forests, perennial plantings, buildings and structures. Immovable things also include the following, if subject to state registration: airships and ocean-going vessels, inland waterway vessels, outer space objects. Other property may be categorized as immovable things by statute. Things that are not categorized as immovables, including money, commercial paper, and securities, are movable property. The registration of rights to movable things is not required except for cases indicated by a statute [Hrazhdanskyi kodeks, 1994].

According to Art. $181 \mathrm{CC}$ to real estate include land, as well as facilities located on the land, the movement of which is impossible without their depreciation and changing their purpose. Immovable things also include the following, if subject to state registration: airships and ocean-going vessels, inland waterway vessels, outer space objects. According to movable things there are things that can be freely moved in space [Tsyvilnyi kodeks 2003].

More to the point, the widening of the regime on immovables to space objects is possible only under direct requirements of the law. That is, all matters related to the space object are within the competence of the state. 
During the 1085th plenary meeting that took place on December 20, 1961 in the General Assembly Hall in New York, United States of America, the General Assembly of the United Nations, after an introduction reaffirming general principles, enacted International Space Law's basis. It was proclaimed that all States have the right to explore outer space [Resolutions, 1961].

It is worth stressing that the Declaration of Legal Principles Governing the Activities of States in the Exploration and Use of Outer Space, RES 1962 (XVIII), General Assembly 18 th session, December 13, 1963, is the second important text concerning Space Law. It is a resolution that was adopted by the General Assembly in 1963. The first important decision concerning Space Law dates back to December 20, 1961. It is the General Assembly Resolution 1721 (XVI) on the International Co-operation in the Peaceful Uses of Outer Space. The latter Declaration reaffirms and expands the scope of the earlier one. The principles contained in it represent the consensus and maximum agreement attainable by the Committee on Peaceful Uses of Outer-Space established by the Assembly to deal with technical co-operation of states and the legal regulation of outer space.

The General Assembly then enounces points that should guide States in the exploration and use of outer space:

1. "The exploration and use of outer space shall be carried on for the benefit and in the interests of all mankind".

2. "Outer space and celestial bodies are free for exploration and use by all States on a basis of equality and in accordance with international law".

3. "Outer space and celestial bodies are not subject to national appropriation by claim of sovereignty, by means of use or occupation, or by any other means".

4. "The activities of States in the exploration and use of outer space shall be carried on in accordance with international law, including the Charter of the United Nations, in the interest of maintaining international peace and security and promoting international cooperation and understanding".

5. "States bear international responsibility for national activities in outer space, whether carried on by governmental agencies or by non-governmental entities, and for assuring that national activities are carried on in conformity with the principles set forth in the present Declaration. The activities of non-governmental entities in outer space shall require authorization and continuing supervision by the State concerned. When activities are carried on in outer space by an international organization, responsibility for compliance with the principles set forth in this Declaration shall be borne by the international organization and by the States participating in it" [Declaration, 1963].

The seventeen articles of the Treaty on Principles Governing the Activities of States in the Exploration and Use of Outer Space, including the Moon and Other Celestial Bodies (adopted on December 19, 1966, entered into force on October 10, 1967) closely follow the 1963 Declaration stating that exploration and use of outer space is for the benefit of all mankind and must be accomplished in accordance with international law and in the interest of peace and international cooperation. Often referred to as the "space constitution," this treaty forms the basis of today's international space law, including provisions regarding use of outer space and a ban on the placement of weapons of mass destruction there [Treaty, 1967]. 
On November 16, 2016, Japan's Space Activities Act was promulgated, establishing a system for licensing the launching of rockets and the operation of satellites by privatesector companies. Almost 20 Western and other countries have already enacted this sort of legislation. Japan is a relative latecomer in this respect. The contents of these laws vary from country to country depending on such factors as whether they have their own launching site or sites and how mature their space activities are. What is more, Aoki Setsuko, Professor of law at Keio University Law School, claims that the Space Activities Act aims to expand Japan's space business. It also provides for government compensation to augment liability insurance coverage against accidents. The aim is to promote broad private-sector participation in space business. Alongside technological development and financing, the design of the legal and regulatory system is a key determinant of success or failure in space business. The new Space Activities Act is sure to give a major boost to this business in Japan, which has both technological strength and great potential. Within the next few years we can expect to see startups launching small rockets carrying miniaturized satellites into orbit [Setsuko, 2017].

Article 8 of the Agreement Governing the Activities of States on the Moon and Other Celestial Bodies uses the term "space object" and defines the term "space vehicle", which includes its equipment, facilities, stations and installations [Agreement, 1979].

Meanwhile, Serhii Vaskov and Servii Malkov point out that a spacecraft, in a legal sense, is a space object or its component part intended to function in outer space. International legal regime of the spacecraft is related to the one of the space object. A distinctive feature of most spacecraft is the ability to function independently in space. While producing a spacecraft design such characteristics as stable high vacuum, weightlessness, intense radiation, the presence of meteorite particles are taken into account. The spacecraft is equipped with scientific instruments, thermoregulation systems, energy conservation, motion control, radio communication with Earth and other spacecraft, life support systems, etc. [Vaskov \& Malkov, 2003: 15].

Despite the name "Space Objects" (Article 17 of the Law of the Russian Federation of August 20, 1993 on Space Activities), the law does not explain the notion of "space object", but only specifies issues of ownership, registration, jurisdiction and control over a particular object. The Article lays down jurisdiction principles regarding space objects. Under those principles, the Russian Federation shall retain jurisdiction and control over space objects registered therein during the time spent by such objects on the ground and at any stage of their flight in outer space or on celestial bodies, and also upon their return to the Earth [Zakon RF, 1993]. However, the Law of Ukraine on November 15, 1996 "On Space Activity" states that objects of space activity (space technology) are material objects of artificial origin that are designed, manufactured and operated in outer space (space segment, space infrastructure) as well as on the Earth's surface (terrestrial segment, terrestrial infrastructure) for the purpose of exploration and use of outer space [Pro kosmichnu, 1996].

It is worthy to mention that by virtue of the existing provisions of international law and the Outer Space Treaty, any person can appropriate space objects, extract minerals, etc. This is exactly what gives rise to various actions of governmental and non-governmental organizations of different states in this direction.

The United States Government updated US commercial space legislation in 2015 with the passage of the Commercial Space Launch Competitiveness Act. The update to US law explicitly allows US citizens to "engage in the commercial exploration and exploitation of space resources including water and minerals". 
In this connection, Dr. Gbenga Oduntan, a Senior Lecturer in International Commercial Law at University of Kent, expressed the view that the 1967 Space Treaty, in principle, prohibits exploitation of potentially finite resources for other than scientific research purposes, the territorial appropriation of real property over celestial bodies by private persons and space experience business. In essence, all of the above is contrary to the idea of the use of outer space for the benefit of humankind. Space could play a key role in assisting developing countries in improving their capabilities. G. Oduntan believes that with respect to space resources, all states should follow the old legal principle of the Romans: Quod omnes tangit, ab omnibus tractari et approbari debet ("What touches all should be considered and approved by all"). The following thought is shared by other scientists [Lefeber, 2016].

"Metalinfo" reports that after the adoption of the US Commercial Space Launch Competitiveness Act, which laid the legal foundations for the private exploration of space and the exploitation of its natural resources, Luxembourg became the first European country and second in the world after the United States to adopt legislation regulating the ownership of resources acquired in space by commercial companies, providing legal certainty for commercial projects in the space sector. This regulation establishes procedures for approving space mining projects, the commercial use of resources and control over project implementation [Luxembourg, 2017].

The law of 20 July 2017 on the exploration and use of space resources (the Space Law), as adopted by the Luxembourg Parliament on 13 July 2017 and effective from 1 August 2017, creates a licensing and supervisory regime in Luxembourg addressing the ownership of resources acquired in space. Similar to the US Commercial Space Launch and Competitiveness Act, the Space Law provides that commercial companies operating within its regulatory framework may legally appropriate resources acquired in space from celestial bodies known as Near Earth Objects (NEOs). Notably, the Space Law does not apply to satellite communications, orbital positions or the use of frequency bands. Unlike the law in the US, the document does not require the companies to depend on Luxembourg, but only to be present on the territory of the country. Already five foreign space companies, including those from the US and Japan, have established formal agreements to start work on the territory of Luxembourg. According to the government, about 60 more enterprises have announced their intention to open representative offices. In a push to diversify Luxembourg's investment funds and banking dominated economy and establish Luxembourg as the European centre of the asteroid mining business, the government has committed 200 million euros to help fund companies set up space exploration related companies [Liuksemburh, 2017].

Geologists believe asteroids are packed with iron ore, nickel and precious metals at much higher concentrations than those found on Earth, making up a market valued in the trillions of dollars. Some of the companies that have signed accords with Luxembourg include USbased companies Deep Space Industries and Planetary Resources, as well as Japanese ispace. With Planetary Resources the link is mostly financial, as the country recently invested more than $\$ 28$ million in the firm to help launch its first commercial asteroid prospecting mission by 2020. As part of the deal, Planetary Resources is setting up a European headquarters in the country, which will conduct key research and development activities in support of its commercial asteroid prospecting capabilities, as well as support international business activities. Luxembourg's administration is also working on a legal frame for exploiting space resources so that private companies can be entitled to the resources they mine from asteroids, but not to own the celestial bodies themselves [Planetary, 2019]. 
The Legal Subcommittee of the Committee on the Peaceful Uses of Outer Space held its fifty-sixth session at the United Nations Office at Vienna in 2017 (A/AC.105/1122). Some delegations expressed the view that the attempts of some States to conduct their space activities while bypassing their obligations under the Outer Space Treaty were a matter of concern. The delegation expressing that view was also of the view that examples of such practice by States included (a) the legitimization of activities conducted by national non-governmental entities in the exploration of space resources that were in contradiction with the provisions of the Treaty; and (b) the establishment of a register or a flag of convenience for private commercial entities interested in pursuing the exploitation of space resources. In that connection, the Subcommittee should seek clarification of key terms, including "common heritage of mankind", "common province of mankind", "national appropriation of outer space" and "exploitation/exploration of space resources" [Annotyrovannaia, 2017].

In fact, there is no entity in international law (not within the U.N. Outer Space Treaty of 1967 or the subsequent Moon Agreement of 1979) that has been established to grant title to any extraterrestrial body, and no sovereign entity can provide for a space resource to be "obtained in accordance with applicable law," because there is no such law. No legal provision exists that would enable a U.S. citizen, or anybody else, to "own, transport, use, and sell the asteroid resource or space resource", nor is there an entity that can provide for the protection of any portion of any celestial body. With this law, Congress is not claiming the required sovereignty or jurisdiction to do so either [Rummel, 2015].

This may be a puzzling outcome for an enacted law, but perhaps it isn't. The real benefit of this law is not the solutions it fails to provide, but that it focuses attention on the need to extend and elaborate the international agreements regarding the "exploration and use of outer space" [Rummel, 2015].

President Donald Trump is unveiling an America first "National Space Strategy" which builds on America's pioneering, spacefaring tradition, laying the groundwork for the next generation of American exploration in space. The Trump administration's National Space Strategy prioritizes American interests first and foremost, ensuring a strategy that will make America strong, competitive, and great. The new strategy emphasizes dynamic and cooperative interplay between the national security, commercial, and civil space sectors. The United States will partner with the commercial sector to ensure that American companies remain world leaders in space technology. The National Space Strategy establishes forthrightly that securing the scientific, commercial, and national security benefits of space is a top priority for this Administration. The National Space Strategy protects vital interest in space - to ensure unfettered access to, and freedom to operate in space, in order to advance America's security, economic prosperity, and scientific knowledge. President Trump has already taken significant steps to reorient American space policy and set it on the right path for the future. On June 30, 2017, the President revived the National Space Council for the first time in 24 years. On December 11, 2017, President Trump once again set America's sights toward the stars by signing Space Policy Directive - 1, which instructed the National Aeronautics and Space Administration (NASA) to return American astronauts to the moon for long-term exploration and utilization, followed by human missions to Mars and other destinations [President, 2018].

Following a recommendation from the National Space Council, President Donald Trump and Vice President Mike Pence asked NASA to accelerate lunar exploration plans and put Americans back on the Moon by 2024, leading to a sustained presence on and around the Moon. The president signed at the White House Space Policy Directive 1, a change in national 
space policy that provides for a U.S. - led, integrated program with private sector partners for a human return to the Moon, followed by missions to Mars and beyond. "Under President Trump's leadership, America will lead in space once again on all fronts", said Vice President Pence.

The UAE is also aiming to build first inhabitable human settlement on Mars by 2117, which means we can expect to see a whole city on another planet in less than 100 years. It will be called the Mars Scientific City, and is part of the long-term Mohammed Bin Rashid Space Centre's Emirates Mars Mission to establish a human colony on the Red Planet. Spread over 1.9 million square feet, the new city will help prepare humans for Mars, featuring a laboratory that will simulate the red planet's terrain and harsh environment through advanced 3D printing technology.

Moreover, in 2014, the Mars Orbiter Mission (MOM) spacecraft, also known as Mangalyaan, arrived at the Red Planet, just two days after NASA's Mars Atmosphere and Volatile Evolution probe (MAVEN) reached Mars orbit. Mangalyaan, which means "Mars craft" in Sanskrit, was the first interplanetary probe ever launched by India [Tymofeev, 2018].

It is important to note that in the absence of clear international rules on space objects, more and more states, under the influence of private business, have taken a political course on the commercialization of space. According to Anton Pervushyn, modern astronautics is largely subordinated to the interests of commerce. As it became clear that the closest planets are uninhabitable and cargo delivery to orbit would long continue to be a complicated matter, priority is given to the establishment and maintenance of a satellite group that solves many commercial objectives: mapping, navigation, broadcasting, space weather monitoring and securing resources [Shykarev, 2018].

From our perspective, modern astronautics is primarily subordinated to the interests of large commercial structures. In other words, as Illia Khel notes, space is open for business. This is how humanity colonizes the suburbs of the Moon, Moon, asteroids, Mars, and other objects - through the cornucopia of a distributed, commercial ecosystem that is much more powerful than any individual company or state [Khel, 2018].

Let us consider the most famous commercial structures in space activities. At the top of the list stands the private company SpaceX (USA) founded in 2002 by Elon Musk with the goal of reducing space transportation costs to enable the colonization of Mars. Some other private companies in the US include: Amazon, Virgin Galactic, Orbital ATK, Rocket Lab (RL). It is also necessary to take into account such big companies as: Interstellar Technologies (Japan), OneSpace (China), which are regularly involved in various commercial space activities.

With the view that space is used for various purposes, the activities of different entities must comply with international law. As Volodymyr Koretsky, the founder of Ukrainian school of international private and public law, once said “... there are international economic relations, so there should be rules governing these relations. If there are norms governing this group of relations, then the system of those norms should have been born" [Koretskyi, 1989: 120-121]. Concurring with the cited opinion, it should be emphasized that the leading role in various space activities should be played, first and foremost, by States themselves.

In all, among the large number of international treaties, conventions, and other acts that may affect the development of mineral extraction in space, the most applicable ones are the following: the Treaty on Principles Governing the Activities of States in the Exploration and Use of Outer Space, including the Moon and Other Celestial Bodies (adopted on December 19, 1966, entered into force on October 10, 1967); the Convention on International Liability for 
Damage Caused by Space Objects (entered into force on September 1, 1972); the Convention on Registration of Objects Launched into Outer Space (commonly known as the Registration Convention which went into force in 1976.); the Convention on Early Notification of a Nuclear Accident entered into force on October 27, 1986; the Convention on Assistance in the Case of a Nuclear Accident or Radiological Emergency came into effect on February 26, 1987; the Principles Relevant to the Use of Nuclear Power Sources in Outer Space adopted by the U.N. General Assembly on 14 December 1992.

Practically speaking, current regulations and rules of international law are not able to solve the existing problems of space, including the ban on the right to the commercial use and sale of space assets. Both the United Nations General Assembly and scientists have repeatedly drawn their attention to the shortcomings in international law on the use of outer space. As an example, in the report of the Committee on the Peaceful Uses of Outer Space, the point was made that a legally binding instrument on the use of space resources for commercial purposes should be created in the near future on the basis of international consensus. For a whole range of reasons, this innovative space industry needs legal certainty. Therefore, a universal, comprehensive convention on outer space should be developed with the aim of finding solutions for existing issues, which would allow the international legal regime to be taken to the next level of its development.

Clearly, there is a question about the need to create an effective international legal act that would address the existing outer space problems, including a common understanding of the principles concerning the use of space assets. The development of science and technology indicates that international organizations in the field of space exploration and use of outer space can no longer accumulate both positive and negative information about space. In this regard, there is the question regarding the establishment of a specialized efficient organization.

The question of creating such an organization is not new. Back in 1969, the Committee on the Peaceful Uses of Outer Space took note of the discussion of the Subcommittee under the item on information on the establishment of international intergovernmental organizations [Kamenetskaia, 1980: 115-117].

Addressing a major issue, the English researcher S. Horsford rightly points out that one of the basic principles of the future activity of such an organization is the discharge its functions on the basis of equal consideration of the interests of all states [Horsford, 1995: 201].

\section{Conclusions}

Indeed, the Moon and its natural resources are the common heritage of mankind and an international regime should be established to govern the exploitation of such resources when such exploitation is about to become feasible. The adoption by the United States and Luxembourg of legislative acts aimed at the legalization, extraction, use and appropriation of space resources by private companies actually violates the principles that outer space and celestial bodies are not subject to national appropriation by claim of sovereignty, by means of use or occupation, or by any other means.

Certainly, one of the most promising directions for implementation and resolution of specific problems is confidence-building in space activities through the development of programme documents that must be authentically interpreted by all subjects of international law. In particular, this refers to the definition of "space objects" and other concepts that have been addressed in United Nations General Assembly resolutions. 
The existing legal framework of international space law is not keeping pace with the development of scientific and technological progress, and the Committee on the Peaceful Uses of Outer Space with its Legal Subcommittees are not able to solve all the pressing problems of space activities. It is also worth pointing out that among the large number of international agreements, conventions and other acts in the field of space activity, some of them are still not signed by the leading space nations.

As a final note, this paper concludes that the path to the adoption of harmonized legal acts and the establishment of an appropriate organization for space activities is not easy and requires the resolution of a number of organizational, economic, legal and political issues. The solution to urgent problems depends on the will of the world's leading States, who must join forces for international cooperation to preserve peace and security.

\section{[ㅁ] References}

Agreement Governing the Activities of States on the Moon and Other Celestial Bodies. Resolution 34/68, General Assembly, 05.12.1979. http://www.unoosa.org/oosa/en/ ourwork/spacelaw/treaties/intromoon-agreement.html

Annotyrovannaia predvarytelnaia povestka dnia. Heneralnaia Assambleia, 27 January 2017. http://www.unoosa.org/res/oosadoc/data/documents/2017/aac_105c_2l/ aac_105c_21_299_0_html/AC105_C2_L299R.pdf

Declaration of Legal Principles Governing the Activities of States in the Exploration and Uses of Outer Space. A/RES/1962(XVIII). A/PV.1280, 13 Dec. 1963. https://undocs.org/ en/A/RES/1962(XVIII)

Halaktyka — nasha! Yaki kosmichni obiekty nosiat ukrainski imena. EtCetera, 22.04.2018. https://uk.etcetera.media/2972-7.html

Hrazhdanskyi kodeks Rossyiskoi Federatsyy: pryniat Hosudarstvennoi Dumoi 21.10.1994 h. № 51-FZ. https://www.grazkodeks.ru/

Horsford, C. E. S. Is I.C.A.O. the Model for an International Space Agency? International Institute of Space Law, Issue 3 1995: 199-203.

Howard, Philip K. There Is No 'Right to Sue'. Wall Street Journal. July 31, 2002.

Kamenetskaia, Elena. Kosmos y mezhdunarodnыe orhanyzatsyy: mezhdunarodno-pravovыe problemы. Moskva: Nauka, 1980.

Khel, Ylia. Kosmos otkrыt dlia byznesa. Chto budet dalshe? Hi-News. ru, 31.07.2018. https:// hi-news.ru/space/kosmos-otkryt-dlya-biznesa-chto-budet-dalshe.html

Konventsiia pro stvorennia Yevropeiskoho kosmichnoho ahentstva. Pidpysannia vid 30.05.1975. https://zakon.rada.gov.ua/laws/show/994_462

Koretskyi, Volodymyr. Vybrani pratsi: U 2 t. Kyiv: Naukova dumka, 1989.

Liuksemburh razreshyl chastnыm kompanyiam dobыvat poleznые yskopaemыe v kosmose. MS “Metallosnabzhenye y sbblt”, 7 yiulia 2017. http://www.metalinfo.ru/ru/news/95759

Lefeber, René. Relaunching the Moon Agreement. Air \& Space Law. Vol. 41. №. 1, 2016: 4148. https://www.kluwerlawonline.com/abstract.php?area=Journals\&id=AILA2016004 Lunar Embassy. 2019. https://lunarembassy.com/

Masson-Zwaan, Tanja, and Bob Richards. International Perspectives on Space Resource Rights. Space News, December 8, 2015. https://spacenews.com/op-ed-internationalperspectives-on-space-resource-rights/ 
Pro kosmichnu diialnist: Zakon Ukrainy vid 15.11.1996 r. № 502/96-VR. Vidomosti Verkhovnoi Rady Ukrainy, 1997. № 1. St. 2.

Planetary resources. 2019. https://www.planetaryresources.com/

Position Paper on Space Resource Mining. International Institute of Space Law. December 20, 2015. http://www.iislweb.org/docs/SpaceResourceMining.pdf

President Donald J. Trump is Unveiling an America First National Space Strategy. March 23, 2018. https://www.whitehouse.gov/briefings-statements/president-donald-j-trumpunveiling-america-first-national-space-strategy/

Rummel, John. D. One Small Step for Space Resources. SpaceNews. December 9, 2015. https://spacenews.com/op-ed-the-next-steps-for-space-resources/

Resolutions and Decisions adopted by the General Assembly. International co-operation in the peaceful uses of outer space. A/RES/1721(XVI), A/PV.1085 20 Dec. 1961.https:// undocs.org/ru/A/RES/1721(XVI)

Shykarev, Serhei. Kosmonavtyka podchynena ynteresam kommertsyy. Ynvest-Forsait. 08. 02. 2018. https://www.if24.ru/kosmonavtika-i-kommertsia/

Setsuko, Aoki. New Law Aims to Expand Japan's Space Business. Nippon Communications Foundation. Mar 3, 2017. https://www.nippon.com/en/currents/d00294/new-law-aimsto-expand-japan $\% \mathrm{E} 2 \% 80 \% 99$ s-space-business.html

Svitlychnyy, Olexander. Ownership of Space Objects. Advanced Space Law, Volume 2, 2018: 76-95. https://doi.org/10.29202/asl/2018/2/10

Space Law: Development and Scope. Edited by Nandasiri Jasentuliyana. Praeger, 1992

Treaty on Principles Governing the Activities of States in the Exploration and Use of Outer Space, including the Moon and Other Celestial Bodies. General Assembly, resolution 2222 (XXI). 27 January 1967. http://www.unoosa.org/oosa/en/ourwork/spacelaw/ treaties/introouterspacetreaty.html

Tsyvilnyi kodeks Ukrainy: Zakon Ukrainy vid 16.01.2003 r. № 435-IV. Vidomosti Verkhovnoi Rady. 2003. №№ 40-44. St. 356.

Tymofeev, Vyktor. SShA, Kytai y Rossyia vыdvyhaiut pretenzyy na Mars - "kholodnaia voina“ mozhet pererasty v „zvezdnыe voinы“. KP v Ukrayne, 30 oktiabria 2018.

Tiahai, Ekateryna. Slozhnostrukturnue modely prava sobstvennosty v SShA. Moskva, 2011. http://www.dslib.net/civil-pravo/slozhnostrukturnye-modeli-prava-sobstvennosti-vssha.html

US Commercial Space Launch Competitiveness Act. July 22, 2015, https://www.congress.gov/ congressional-report/114th-congress/senate-report/88/1

Vaskov, Serhei, Malkov, Serhei. Normatyvno-pravovoe obespechenye kosmycheskoi deiatelnosty. Sankt-Peterburh, 2003.

Zakon KNR "O veshchnыkh pravakh". Ot 16.03.2007. https://chinalaw.center/civil_law/ china_real_rights_law_2007_russian/

Zakon RF ot 20 avhusta 1993 h. № 5663-I "O kosmycheskoi deiatelnosty" (s yzmenenyiamy y dopolnenyiamy). http://base.garant.ru/136323/ 